\title{
Mandatory IFRS adoption and the cost of equity capital: Evidence from Spanish firms
}

\author{
David Castillo-Merino ${ }^{1}$, Carlota Menéndez-Plans ${ }^{2}$, Neus Orgaz -Guerrero ${ }^{3}$ \\ ${ }^{1}$ IQS School of Management- Universitat Ramon Llull (IQS-URL) (Spain) \\ ${ }^{2}$ Universidad Autónoma de Barcelona (UAB) (Spain) \\ ${ }^{3}$ Universitat Oberta de Catalunya (UOC) (Spain) \\ david.castillo@iqs.edu, carlota.menendez@uab.es,norgaz@uoc.edu
}

Received December, 2013

Accepted May, 2014

\section{Abstract}

Purpose: The main objective of this paper analyses the effects of mandatory International Financial Reporting Standards (IFRS) adoption by Spanish firms in 2005 on the cost of equity capital.

Design/methodology/approach: Using a sample of listed Spanish companies during the 1999 to 2009 period and a country-level focused analysis. To achieve our objective we relied on OLS regression analysis and estimate the dependent variable - the cost of equity - by using the proxy suggested in Easton (2004).

Findings: We find evidence that, unlike previous studies, Spanish listed companies show a significant reduction in their cost of equity capital after the mandatory adoption of IFRS in 2005, after controlling by a set of firm-risk and market variables. According to our results, increased financial disclosure and enhanced information comparability, along with changes in legal and institutional enforcement, seem to have a joint effect on the cost of capital, leading to a large decrease in expected equity returns.

Research limitations/implications: The main limitation of the study is that the sample represents just one country. 
Practical implications: The findings of the study may have implications for the firms' management staff, as they reveal what information determines the cost of equity capital. The systematic risk and the leverage affect positively the cost of stocks and therefore their market value. The results are consistent with the financial principle establishing that the higher risk and the higher leverage, the higher cost of capital.

Originality/value: As a result of the conducted research, one is able to figure out which stock-return variables should be observed to anticipate the change of a company's cost of capital.

Keywords: International Financial Reporting Standards (IFRS), mandatory IFRS adoption, cost of equity capital, financial disclosure

Jel Codes: M41, G32

\section{Introduction}

Beneficial capital-market effects from enhancing quality and comparability of accounting information are a major issue in today's accounting research.

Recent research in this field has demonstrated that firms from countries with more extensive disclosure requirements, stronger securities regulation, and stricter enforcement mechanisms have a significantly lower cost of capital (Hail \& Leuz, 2006).

The belief that higher mandate disclosure of accounting information by firms should reduce its cost of equity capital has led many countries to adopt International Financial Reporting Standards (IFRS) as a new and unique set of accounting standards. In this line, The European Union (EU) has mandated that all EU-listed groups of companies adopt IFRS beginning in 2005 with the goal of reaching an increase of the capital markets' efficiency and, thus, protecting investors' interests.

However, there is still little empirical evidence of these positive effects from IFRS mandatory adoption. In fact, most of previous studies have found some evidence that voluntary IFRS adoption reduces the cost of capital (Leuz \& Verrecchia, 2000; Daske, 2006; Barth, Landsman \& Lang, 2008; Karamanou \& Nishiotis, 2009; Hai,I Leuz \& Wysocki, 2010), but there is little empirical evidence supporting this relationship for mandatory IFRS adoption, and they show to some extent different results. Daske, Hail, Leuz and Verdi (2008) demonstrate that there is an average market liquidity increase around IFRS introduction, a decrease in firms' cost of capital and an increase in equity valuation, but only prior to the official adoption date, and some market-capital benefits that only appear to be significant in countries where firms have 
incentives to be transparent and where legal enforcement is strong. Unlike this study, $\mathrm{Li}$ (2010) finds consistent evidence that the IFRS mandate is associated with a significant reduction in the cost of equity capital for mandatory adopters.

Mandated disclosures could reduce the cost of capital through at least two different paths: increasing the quality of financial disclosure and enhancing information comparability. However, empirical evidence suggesting that the positive effects of IFRS adoption on the cost of capital can only emerge if the improve in quality reporting and the enhanced information comparability across firms is consistent with firms' reporting incentives and enforcement mechanisms (Li, 2010; Daske et al., 2008).

In the EU the shift to a new accounting regulation has been accompanied with several institutional changes, such as the Financial Services Action Plan (FSAP) in 1999 or the series of directives to improve financial market regulation (for instance, insider trading regulation). These institutional changes can modify firms' reporting incentives leading to better quality disclosures and, thus, to a lower cost of capital.

The investigation of mandatory IFRS adoption shows, however, some unsolved problems. As many countries with different enforcement regimes and institutional structures adopted the IFRS around the same it is in practice difficult to disentangle the effects stemming from the shift in the information disclosure from other "external effects" (such as unrelated institutional changes or economic shocks) as well as to identify whether the effects are evidenced just around the time of the introduction of IFRS or, instead, they remain over time.

There are two remarkable reasons why Spain provides an appropriate environment for analysing potential join effects from mandatory adoption of the international accounting standards. First, the adoption of IFRS in Spain has led to an improvement of the quality of the accounting information disclosed by companies (Christensen, Hail \& Leuz, 2013). Second, the introduction of international accounting standards for companies' financial statement disclosure has promoted changes in the enforcement and institutional framework (Burgstahler, Hail \& Leuz, 2006). The jointly effect of all these changes may have a feedback positive market effect for adopters.

We specifically test whether mandatory IFRS adoption in Spain affects the cost of equity capital by regressing the estimated cost of capital on a set of test variables, capturing the single effect of the IFRS mandatory adoption on the expected returns of Spanish firms' stocks.

The findings in the abovementioned analysis show that, unlike previous studies, Spanish firms experience a significant reduction of cost of equity capital after the mandatory IFRS 
introduction in 2005. These results are consistent with the assertion that mandatory IFRS adoption should significantly lower firms' cost of equity capital.

This study contributes to the extant literature on the economic consequences of disclosure regulation by providing evidence of the effects of mandatory IFRS adoption on firms' cost of equity capital in a single country and with additional data in the post-adoption period. This focused analysis allows us to disentangle country-level effects from cross-sectional comparisons leading to different results than in comparative international studies.

Thus, the findings of this study contribute to an ongoing debate as to whether the quality of accounting information affects firms' cost of equity capital ( $\mathrm{Li}, 2010$ ). To the extent that IFRS represents a set of high-quality accounting standards, this study provides evidence consistent with high-quality financial reporting lowering the cost of equity capital.

The remainder of the work is organized as follows. Section 2 provides a background and literature review on the analysis of the relationship between accounting information's disclosure and the cost of capital. Section 3 presents the study's hypothesis and the data set, and discusses the research method. Section 4 shows the main results, and section 5 concludes the paper with implications, limitations, and future research suggestions.

\section{Literature review}

\subsection{Information disclosure and the cost of capital}

The extent to which firms benefit from increased disclosure is one of the most important issues in today's research in accounting. One of these advantages should come from the effect of higher disclosure of accounting information by firms on the reduction in the cost of capital.

This relation between cost of equity capital and disclosure has been investigated in recent years by several theoretical and empirical studies. From the theoretical point of view it has been argued that disclosure reduces information asymmetry, and consequently reduces firms' cost of equity capital through reduced bid-ask spreads (Amihud \& Mendelson, 1986) or through increased demand for a firm's securities (Diamond \& Verrecchia, 1991). Another possible benefit of better disclosure quality is that better information reduces potential investors' estimation risk regarding the parameters of a security's future stocks' return. It is assumed that investors attribute more systematic risk to an asset with low information than to an asset with high information (Clarkson, Guedes \& Thompson, 1996). 
Despite of these well-known arguments about the beneficial incidence of the quality of accounting information disclosure on the cost of capital, the theoretical debate still remains open. In fact, one of the most controversial and fundamental issues within the theoretical literature is the issue of the diversifiability, or nondiversifiability, of information effects. In other words, one of the main sources of debate is whether information risk is a priced risk or whether it is, instead, diversifiable.

In this regard, and holding support for non-diversifiable rationale, Easley and O'Hara (2004) proposed a rational expectations model within which information can affect a firm's cost of equity capital. Firms can influence their cost of capital by affecting the precision and quantity of information available to investors. Further, they suggest that this can be accomplished by a firm's selection of its accounting standards, as well as through its corporate disclosure policies.

Continuing with this argument, Lambert, Leuz and Verrecchia (2007), develop a framework that links the disclosure of accounting information to the cost of capital. Specifically, they examine whether and how the quality of a firm's accounting information manifests in its cost of capital. Using this framework, they demonstrate that the quality of accounting information influences a firm's cost of capital, both directly by affecting market participants' perceptions about the distribution of future cash flows, and indirectly by affecting real decisions that alter the distribution of future cash flows. The direct effect occurs because the quality of disclosures affects the assessed covariances between a firm's cash flow and other firms' cash flows. This effect is not diversifiable in large economies. Their finding provides a direct link between the quality of a firm's disclosures and accounting policies and its cost of capital.

These results evidencing that accounting information can lower a firm's cost of capital contrasts with the work by Hughes, Lui and Liu (2007) and Christensen, de la Rosa and Feltham (2010). The paper by Hughes et al. (2007) only analyzes the direct effect of information, and concludes that only the marketwide risk premium changes; information has no crosssectional effect. Meanwhile, Christensen et al. (2010) approach the link between information and cost of capital from a longer-term perspective, arriving at a somewhat different conclusion. They note that the studies reviewed earlier focus exclusively on cost of capital for the period after the release of information and argue the analysis is therefore incomplete because the impact of information on the risk premium in the period leading up to the release of the information is being ignored. They then suggest the possibility that the reduction in the cost of capital during the post-release period can be offset by an increase in the cost of capital during the pre-release period. Specifically, they argue that the more informative the forthcoming public report, the greater the amount of uncertainty that will be resolved upon the release of the report. Hence, the return for the period leading up to the 
release of the public report will be more risky, and the risk premium for this period will be higher. Thus, if these effects directly offset, there would be no impact on ex ante cost of capital covering the full time span of the firm.

It is likely that the question of diversifiability can only be solved empirically (Artiach \& Clarkson, 2011). But the empirical evidence on this matter is mixed. As pointed out by Espinosa and Trombetta (2007), the lack of conclusive results in this area may be due in part to measurement difficulties of the cost of equity capital and to model specification issues, as models fail to consider the possible effect of different accounting policy choices.

The interaction between accounting policy choice and disclosure can also provide a possible explanation of the mixed results obtained so far in the empirical literature with respect to the supposed positive effect of transparency on the cost of equity capital (Espinosa \& Tombetta, 2007).

There are quite a few empirical studies that have dealt with the positive effect of disclosure on the cost of equity capital. Botosan and Plumlee (2002) estimate cost of capital using four alternative methods, and they find that after controlling for firm size and market beta, more timely disclosure is associated with a lower cost of capital. Hail (2002), shows a negative and highly significant relation between the cost of equity capital and disclosure. Leuz and Verrecchia (2000) find that increased disclosure implies lower bid-ask spreads and higher share turnover, after controlling for several firm characteristics.

More recently, some works have introduced new elements to shed light on this matter trying to disentangle how the link between information disclosure and the cost capital runs in practice. In this sense, Hail and Leuz (2006) analyse international differences in firms' cost of capital across 40 countries. Particularly, they investigate whether the effectiveness of a country's legal institutions and securities regulation is systematically related to cross-country differences in the cost of equity capital. Their results show that firms from countries with more extensive disclosure requirements, stronger securities regulation, and stricter enforcement mechanisms have a significantly lower cost of capital.

Espinosa and Trombetta (2007) investigate the relationship between disclosure and cost of equity capital, demonstrating the existence of an interaction effect between the accounting policy adopted by firms and the level of disclosure of other relevant information. They first estimate a model between disclosure and cost of equity capital without taking into account accounting policy choice. With this model they are not able to find any significant evidence in favour of an inverse relationship between disclosure and the cost of equity capital. However, when they take into account accounting policy choice, proxied by the sign of discretionary 
accruals, they find that the inverse relationship exists for aggressive firms (a higher level of disclosure leading to a reduction on the cost of capital), whereas it is not significant for conservative firms. Thus, the authors state that the interaction between accounting policy choice and disclosure can also provide a possible explanation of the mixed results obtained so far in the empirical literature with respect to the supposed positive effect of transparency on the cost of equity capital: accounting policy may be an omitted variable in the model estimated so far.

Reverte (2009) investigates whether higher quality governance is associated with a lower cost of equity capital. He focuses on five board characteristics that have received widespread attention in corporate governance literature (board independence, board size, existence of both audit and nomination/remuneration committees, CEO duality, and independence of board committees). His results for a sample of listed Spanish firms indicate that stronger governance firms enjoy a statistically significant reduction in the cost of equity capital with respect to firms with weaker governance, after controlling for beta, size and market-to-book. Therefore, the paper suggests that the agency risk attributable to governance quality is not diversifiable. Investors not only expect lower future cash flows for weak governance firms, but they also discount the expected future cash flows at a higher rate.

The interactions between the accounting information disclosure and the use of graphs in corporate annual reports (together with the frequency with which they are displayed) have been also a matter of investigation. In this regard, Muiño and Trombetta (2009) show that graphs in corporate reports are usually distorted and used to portray a more favourable view of corporate performance. They investigated these effects in the Spanish market and their results show that market disclosure interacts also with graph distortion as a determinant of the cost of equity.

From an analytical point of view, Bertomeu, Beyer and Dye (2011) develop a model that jointly explains a firm's voluntary disclosure policy, its capital structure, and its cost of capital. Through this model, the authors demonstrate that there exist interdependences between a firm's capital structure and its disclosure policy when analyzing the effects of corporate information disclosure on the cost of capital. These interdependencies imply that, in equilibrium, a firm's capital structure and disclosure policy are jointly determined, and together determine the firm's cost of capital.

Finally, another important setting within this field is the impact of mandated disclosures or accounting policies on firms' cost of capital. It is assumed that increasing the quality of mandated disclosures should generally reduce the firms' cost of capital. A significant portion of 
its impact on the cost of capital of firms occurs through lowering the market risk premium (Lambert et al., 2007).

In this line, standard setters frequently refer to it, suggesting that high quality accounting standards may reduce capital costs. In fact, there exits the intuition that more information always equates to less uncertainty, and, in the context of financial information, the end result is that better disclosure results in a lower cost of capital. While these claims have intuitive appeal, there is little empirical evidence on the connection between accounting standards, and in particular the adoption of international accounting standards (IFRS) by firms, and firms' cost of equity capital.

\subsection{The cost equity effects of mandatory IFRS adoption}

According to previous theoretical and empirical evidence in this field, mandated disclosures, as the legal requirement of the International Financial Reporting Standards (IFRS) adoption in the $\mathrm{EU}$, can reduce the cost of capital through at least two different paths: increasing the quality of financial disclosure and enhancing information comparability.

IFRS usually are more capital-market oriented and more comprehensive, particularly in terms of disclosure requirements, than local accounting standards (Daske et al., 2008). This higher quality financial reporting and better disclosure reduce adverse selection problems in stock markets, enhancing liquidity and allowing for a decrease in the cost of equity, through diminishing transaction costs, stronger demand for securities (Easley and O'Hara, 2004) and lower forward-looking betas (Francis, Khurana \& Pereira, 2005; Lambert et al., 2007).

A second argument for explaining the beneficial effects of IFRS adoption on the cost of equity capital is that a uniform set of accounting standards can improve comparability of financial information of firms across markets and countries, making the use of information less costly for investors and, in turn, reducing information asymmetries and leading to a lower cost of capital (Covrig, Defond \& Hung, 2007). The impact of information comparability on firms' cost of capital seems to be a critical issue. In fact, even if the quality of corporate reporting is not enhanced by the mandatory adoption of IFRS, the financial information provided by firms in different markets and countries is still very useful to investors as IFRS reporting enhances the comparison across firms and drops estimation risk (Daske et al., 2008; Lambert et al., 2007).

There is, however, empirical evidence suggesting that the positive effects of IFRS adoption on the cost of capital can only emerge if the improve in quality reporting and the enhanced information comparability across firms is consistent with firms' reporting incentives and 
enforcement mechanisms ( $\mathrm{Li}, 2010)$. In other words, it is unclear that mandating the use of IFRS alone makes financial information more informative or comparable (Daske et al., 2008). In fact, reporting incentives and enforcement play an important role in explaining the positive impact of IFRS mandatory adoption as capital-market effects have only emerged in countries with strong institutions and legal systems. This is the reason why many countries have made enforcement changes (i.e. the creation of enforcement authorities that assume responsibility for IFRS compliance, governance and auditing reforms) along with the switch in accounting standards to support it, and it seems to be this bundle that is responsible for the positive capital-market outcomes (Christensen et al., 2013).

In the case of the mandatory IFRS adoption in the EU, the shift to a new accounting regulation has been accompanied with several institutional changes, such as the Financial Services Action Plan (FSAP) in 1999 or the series of directives to improve financial market regulation (for instance, insider trading regulation). These institutional changes can modify firms' reporting incentives leading to better quality disclosures and, thus, to a lower cost of capital.

As many countries with different enforcement regimes and institutional structures adopted the IFRS around the same, it is in practice difficult to disentangle the effects stemming from the shift in the information disclosure from other "external effects" (such as unrelated institutional changes or economic shocks) as well as to identify whether the effects are evidenced just around the time of the introduction of IFRS or, instead, they remain over time.

There are, thus, some unsolved questions that can be addressed through a focused analysis on particular countries in order to get to comparable results that may avoid the abovementioned "noisy" effects. To move forward in this direction we have selected Spain, because, differently to other EU members, the mandatory adoption of the international accounting standards in Spain has led to an increase of the quality of the information disclosed by companies, along with an enhance of enforcement regimes and institutional structures. The jointly effect of all these changes may is expected to be a rise of reporting incentives for companies, that are required to observe a stricter legal system (mainly in the fields of quality of disclosure, auditing and corporate governance), that, in turn, has a feedback positive effect on the quality of information disclosure. In fact, Spain was one of the EU members with weaker enforcement mechanisms in the pre-period to IFRS adoption (Burgstahler et al., 2006), the country in the EU with the highest number of inconsistencies between local standards and IFRS and with the largest level of additional disclosure required by IFRS relative to local standards (Li, 2010).

While previous studies have found some evidence that voluntary IFRS adoption reduces the cost of capital (Leuz \& Verrecchia, 2000; Daske, 2006; Barth et al., 2008; Karamanou \& Nishiotis, 2009; Hail et al., 2010), there is little empirical evidence supporting the 
abovementioned relationship for mandatory IFRS adoption, and they show to some extent different results. The more related studies to our paper are exhibited below.

Daske et al. (2008) examine the economic consequences of mandatory IFRS reporting on market liquidity, cost of capital and Tobin's q across 26 countries. Their results show a threefold evidence:

- An average market liquidity increase around IFRS introduction;

- A decrease in firms' cost of capital and an increase in equity valuation, but only prior to the official adoption date; and

- Market-capital benefits only appear to be significant in countries where firms have incentives to be transparent and where legal enforcement is strong.

Similarly to our study, Li (2010), using a focused EU sample, additional data in the postadoption period, a difference-in-differences research design, and tests to account for a transition effect, she finds consistent evidence that the IFRS mandate is associated with a significant reduction in the cost of equity capital for mandatory adopters, but, unlike our work, finds no significant effect for voluntary adopters at the time of mandatory adoption. She also shows how disclosure and enhanced comparability are two of the possible mechanisms behind the cost of equity effects.

These results reinforce the hypothesis about a bundled positive effect between the mandatory adoption of IFRS and the enforcement of the information reporting.

\section{Research design}

\subsection{Methodology}

This paper explores the impact of mandatory IFRS adoption on the cost of equity capital of Spanish firms. Formally, the hypothesis that we aim to verify can be stated as follows:

- $\mathrm{H}$ : The mandatory adoption of IFRS in 2005 by Spanish firms explains a decrease in the firms' cost of equity capital.

As in prior research, we regress the cost of equity capital on a set variables, setting the mandatory IFRS adoption as a control variable in order to isolate the contribution of new information reporting as an explanatory variable on the firms' cost of capital. 
The cost of equity capital is defined as the market discount rate that equates a stock's future expected returns with its current price. It is not directly observable and for its estimation we have found two streams in the literature: ex-post estimates, based on realized returns, and exante estimates, based on analysts' forecasts. The former has been criticized for being inaccurate as it is not a reliable proxy for the cost of equity capital (Reverte, 2009), showing potential problems to identify the right asset pricing model, imprecision in the estimate of factor loadings and in the estimate of factor risk premium (Fama \& French, 1997). For estimating the cost of equity capital under the ex-ante perspective, authors compute the implied cost of capital for each firm by forecasting variables (mainly earnings and book value) up to a terminal period and to set a suitable terminal value to capture the value of the accounting variables beyond the terminal period (Espinosa \& Trombetta, 2007). There are different alternative proxies for the calculation of this firm-specific cost of equity capital or expected return. Botosan, Plumlee and Wen (2011) assess the reliability of the methods used under both approaches and providing additional evidence to the construct validity of the proxies employed in extant research. They find that realized returns do not proxy for the cost of equity capital, even after controlling for new variables, and recommend researchers the indistinct use of the PEG method (Easton, 2004), also called $r_{P E G}$, or the target price method, r DIv (Botosan \& Plumlee, 2002). These two methods provide cost of equity capital estimates that are consistently and predictably related to risk and consistently demonstrate the greatest degree of construct validity. Similar conclusions are provided by Artiach and Clarkson (2011) concerning the PEG method.

Based upon these results, we use in this paper the Easton (2004) $r_{P E G}$ proxy for estimating the cost of equity capital of a firm's stocks in period t by setting up the following model:

$$
r_{P E G, t}=\left[\left(e p s_{t+2}-e p s_{t+1}\right) / P_{0}\right]^{1 / 2}
$$

Where:

$$
\begin{aligned}
& r^{\mathrm{PEG}, \mathrm{t}} \text { the cost of equity capital at } t \\
& \text { eps }_{\mathrm{t}+2} \text { consensus forecasts of earnings per share at } t+2 \\
& \text { eps }_{\mathrm{t}+1} \text { consensus forecasts of earnings per share at } t+1 \\
& \mathrm{P}_{\mathrm{o}} \quad \text { the stock's price at the end of the fiscal year } t
\end{aligned}
$$

Although in previous research different terms of forecasted earnings are displayed, we have used one-year and two-year ahead, respectively, made as of the end of year $t$, as it seems to 
be a certain consensus on it in the literature (Muiño \& Trombetta, 2009; Reverte, 2009; Lee, Mande \& Soon, 2009).

According to prior theoretical and empirical research, the measure of expected return seems to be positively related to beta (Muiño \& Trombetta, 2009; Lee et al., 2009) leverage (Damodaran, 2010) and inflation rate (Gosnell \& Nejadmalayeri, 2010), and negatively related to size (Li, 2010), GDP's growth (Vassalou, 2003) and the average return in the capital market (Kofman \& Martens, 1997). Additionally, we have also included firms' return on assets (ROA) and return on equity (ROE) that are expected to be negatively correlated with a firm's cost of equity capital as well.

These independent variables are classified in three different set of variables:

- Embedded variables based on firms' accounting information.

- External variables, concerning the market influence.

- A control variable, in order to capture the effect of mandatory IFRS adoption on firms' cost of equity capital.

\begin{tabular}{|c|c|}
\hline \multicolumn{2}{|c|}{ Embedded variables } \\
\hline Variable & Description \\
\hline Size (SZ) & Log of total assets ( $\mathrm{Li}(2010))$ \\
\hline Leverage (LEV) & $\begin{array}{l}\text { Non-current liabilities over equities plus non- } \\
\text { current liabilities (Damodaran (2010)) }\end{array}$ \\
\hline Return on Equity (ROE) & Net Income / Equities \\
\hline Return on Assets (ROA) & EBIT / Total Assets \\
\hline \multicolumn{2}{|c|}{ Market variables } \\
\hline Variable & Description \\
\hline B & $\begin{array}{l}\text { Regression coefficient between stocks' market } \\
\text { returns and the return of the market portfolio, } \\
\text { the IBEX-35 index, as a proxy of the companies } \\
\text { stocks' systematic risk (Muiño \& Trombetta, } \\
2009 \text {; Lee et al., 2009) }\end{array}$ \\
\hline Inflation (IR) & $\begin{array}{l}\text { Annual changes in the inflation rate (Gosnell \& } \\
\text { Nejadmalayeri, 2010). }\end{array}$ \\
\hline GDP & Annual change in GDP (Vassalou,2003). \\
\hline Dow Jones (DJ) & $\begin{array}{l}\text { Annual return in the Dow Jones index. Kofman } \\
\text { and Martens (1997) conclude that US capital } \\
\text { markets influence the stock performance in } \\
\text { other European markets, as UK. }\end{array}$ \\
\hline \multicolumn{2}{|c|}{ Control variables } \\
\hline Variable & Description \\
\hline IFRS & $\begin{array}{l}\text { Dummy variable to control for the effect of } \\
\text { mandatory IFRS adoption on the cost of capital. }\end{array}$ \\
\hline
\end{tabular}

${ }^{1}$ To estimate beta values we have used the daily returns of stocks and the daily returns of the market portfolio IBEX-35 index. We have estimated an annual beta for each firm according to the following regression model: $R_{i t}=\alpha_{i}+\beta_{i a} R_{M t}+\mu_{i t}$ 
The formal regression model is as follows:

$$
\begin{aligned}
& r_{P E G i, t}=\alpha_{0}+\alpha_{1} \mathrm{SZ}_{i, \mathrm{t}}+\alpha_{2} \mathrm{LEV}_{i, \mathrm{t}}+\alpha_{3} \mathrm{ROE}_{\mathrm{i}, \mathrm{t}}+\alpha_{4} \mathrm{ROA}_{\mathrm{i}, \mathrm{t}}+\alpha_{5} \beta_{\mathrm{i}, \mathrm{t}}+\alpha_{6} \mathrm{IR}_{\mathrm{t}}+\alpha_{7} \mathrm{GDP}_{\mathrm{t}}+\alpha_{8} \mathrm{DJ}_{\mathrm{t}} \\
& +\alpha_{9} \mathrm{IFRD}+\epsilon_{\mathrm{i}, \mathrm{t}}
\end{aligned}
$$

Where:

$r_{P E G, t}$ is the cost of equity capital (ex-ante returns) of the firm i in year $t$

$S Z_{i, t} \quad$ is the size of the firm $i$ in year $t$

$L E V_{i, t}$ is the financial leverage of the firm $i$ in year $t$

$\mathrm{ROE}_{i, t}$ is the return on equity of the firm $i$ in year $t$

$R O A_{i, t}$ is the return on assets of the firm $i$ in year $t$

$\beta_{i, t} \quad$ is the stocks beta for the firm $\mathrm{i}$ in year $\mathrm{t}$

$I R_{t} \quad$ is the inflation rate variation in Spain in year $t$

$\mathrm{GDP}_{\mathrm{t}}$ is the change of Spanish GDP in year $\mathrm{t}$

$D J_{t} \quad$ annual return of the Dow Jones index en el period $t$

IFRS indicator variable equal to 0 for the years before 2005 and equal to 1 for 2005 and onwards.

$\epsilon_{i, t} \quad$ is the random error

We have estimated our model using an OLS method. The research design has been as follows. First, we have specified and regressed a basic model excluding IFRS variable to analyse the influence of embedded and market variables on the cost of equity capital as well as to confirm the expected sign. Then, we have included the IFRS indicator variable to our former model to isolate the effect of the shift to a new accounting regulation on stocks' expected returns.

\subsection{Sample selection}

We have built up a database of listed companies in the Spanish IBEX-35 index for the fiscal years 1999-2009, generating 28 firm-year observations of full data1, including 307 
observations for estimating the cost of capital and for measuring the set of independent variables. The source of our database has been as follows:

- Osiris database, from where we have obtained the firm-level accounting information.

- Web page http://finance.yahoo.com, from where we have got the stocks' daily prices required for beta estimations.

- From http://bolsademadrid.com we have been provided with the value of the IBEX-35 index, required as well for estimating beta values.

- The Journal Bolsas y Mercados Españoles has been the source of the analysts' forecasts on firms' earnings per share.

The size of our sample is constrained by the lack of access to a largest database containing analysts' forecasts, such as the I/B/E/S (Institutional Broker Estimate System) or JCF.

To obtain the cost of equity capital measures, we have used the information in the table "Estimaciones de Consenso Valores IBEX-35" from the Journal "Bolsas y Mercados Españoles".

The data available has allowed us to estimate a single cost of equity capital for each firm and for 11 fiscal years, 1999-2009.

\section{Results}

\subsection{Descriptive statistics}

Table 2 reports the descriptive statistics for the variables used in the sample.

\begin{tabular}{|c|c|c|c|}
\hline Variable & Obs & Average & Standard deviation \\
\hline $\mathrm{r}_{\mathrm{PEG} 1999-2004}$ & 112 & 0,184 & 0,263 \\
\hline $\mathrm{r}_{\mathrm{PEG} 2005-2009}$ & 196 & 0,119 & 0,162 \\
\hline$r_{\text {PEG1999-2009 }}$ & 307 & 0,158 & 0,223 \\
\hline$\beta$ & 307 & 0,290 & 0,379 \\
\hline $\mathrm{SZ}$ & 307 & 16,09 & 2,263 \\
\hline LEV & 307 & 0,508 & 0,228 \\
\hline $\mathrm{ROE}$ & 307 & 0,145 & 0,304 \\
\hline ROA & 307 & 0,070 & 0,115 \\
\hline IR & 307 & 2.97 & 1,134 \\
\hline GDP & 307 & 2,305 & 1,457 \\
\hline DJ & 307 & $-0,011$ & 0,121 \\
\hline
\end{tabular}

Table 2. Descriptive statistics 
Data reported in the table 2 shows that the average cost of capital calculated for the entire sample is $18.4 \%$. When this sample is divided into two subsamples for periods $1999-2004$ and 2005-2009, we see that the cost of capital during the later period is lower on average than the cost in the earlier period. Starting from 2005 the average cost of stocks (the cost of equity) as well as its standard deviation is reducing. The table shows also that the average beta of the whole sample is 0.29 , evidencing a sort of "secure" profile of stocks traded in the IBEX-35 index. The return on equity has been, in average for the period 1999-2009, of $14.47 \%$, being the average value for the return on assets equal to $7 \%$ and the firms' leverage of $50.75 \%$. Interestingly, the estimated average value of the cost of equity value (i.e., the required return for the stocks of Spanish companies) has amounted to $15.8 \%$, showing a higher value than the actual return to stakeholders (14.47\%). Size is far the variable with the largest standard deviation, thus a significant effect is expected, and return on assets shows the lowest one.

\subsection{Correlation between test variables}

Table 3 reports the Pearson correlation coefficients for the test variables of the full sample, allowing to set up a regression model without collinearity problems. We find a significantly negative correlation between the cost of equity capital and the firm-level beta and positive correlation between the cost of capital and financial leverage.

Regarding the correlation between test variables, we just find a high correlation coefficient between the annual variation of the inflation rate and the annual growth in GDP, and between the annual variation of the inflation rate and the annual market return in the Dow Jones index.

\begin{tabular}{|c|c|c|c|c|c|c|c|c|c|c|}
\hline & $\mathbf{r}_{\mathrm{PEG}}$ & $\boldsymbol{\beta}$ & Sz & LEV & ROE & ROA & IR & GDP & DJ & IFRS \\
\hline$r_{P E G}$ & 1 & & & & & & & & & \\
\hline$\beta$ & $-0,1568$ & 1 & & & & & & & & \\
\hline SZ & 0,0969 & 0,2299 & 1 & & & & & & & \\
\hline LEV & 0,1492 & 0,1451 & 0,5097 & 1 & & & & & & \\
\hline ROE & 0,0966 & 0,0165 & 0,3791 & 0,1838 & 1 & & & & & \\
\hline ROA & $-0,0853$ & $-0,0787$ & $-0,2540$ & $-0,2244$ & $-0,0223$ & 1 & & & & \\
\hline IR & 0,0654 & $-0,5232$ & $-0,1264$ & $-0,1332$ & $-0,0004$ & 0,1010 & 1 & & & \\
\hline GDP & 0,1255 & $-0,5417$ & $-0,1568$ & $-0,2086$ & $-0,0115$ & 0,0672 & 0,7266 & 1 & & \\
\hline DJ & 0,0091 & $-0,1824$ & $-0,0362$ & $-0,0038$ & 0,0138 & 0,0839 & 0,7295 & 0,4145 & 1 & \\
\hline IFRS & $-0,126$ & 0,489 & 0,1539 & 0,2095 & 0,0107 & $-0,052$ & $-0,593$ & $-0,974$ & -0243 & 1 \\
\hline
\end{tabular}

$r_{\text {PEG }}$ (estimated cost of equity capital), $\beta$ (systematic stocks' risk), SZ (Firm's size), LEV (firm's leverage), ROE (return on equity), ROA (return on assets, IR (annual inflation rate variation), GDP (annual growth in GDP), DJ (annual return of the Dow-Jones index), IFRS is indicator variable equal to 0 for the years before 2005 and equal to 1 for 2005 and onwards.

Table 3. Pearson correlation matrix 


\subsection{Models and results}

The results presented below are the best ones obtained after:

- Selecting the independent variables one by is using OLS. Based on all available information we incorporate in the model 1 and 2 only the variables shown to be a statically significant in OLS regression with the cost of equity capital.

- Considering the correlation coefficient between individually significant independent variables. We consider only uncorrelated variables to avoid a collineariaty problem.

In table 4 we exhibit the results of the multivariate regression analysis using the best estimated models for avoiding autocorrelation and heterocedasticity. Model 1 is the model that better fits the data to capture the significant effects of the test variables on the cost of equity capital. Model 2, instead, is the best model to isolate the incidence of IFRS mandatory adoption by Spanish firms on their stocks' expected returns.

\begin{tabular}{|c|c|c|}
\hline Variable & Model 1 & Model 2 \\
\hline$\alpha_{0}$ & $0.055(0.12)$ & $0.1056(3.09)$ \\
\hline$\beta$ & $0.079(2.03) * *$ & $0.063(1.75)^{*}$ \\
\hline LEV & $0.172(3.02) * * *$ & $0.1713(3.01) * * *$ \\
\hline ROE & $0.05(1,20)$ & $0.049(1.17)$ \\
\hline GDP & $0.138(1.34)$ & \\
\hline IFRS & & $-0.15(-1.72)^{*}$ \\
\hline No observations & 307 & 307 \\
\hline $\mathrm{R}^{2}$ & 0.0526 & 0.049 \\
\hline \multicolumn{3}{|c|}{$\begin{array}{l}\beta \text { (systematic stocks' risk), LEV (firm's leverage), ROE (return on equity), GDP (annual } \\
\text { growth in GDP), DJ (annual return of the Dow-Jones index), IFRS (dummy variable } \\
\text { measuring the mandatory IFRS adoption by firms) } \\
*, * *, * * * \text { Denotes significance at the } 0.10,0.05 \text { and } 0.01 \text { level. T-student is exhibited in } \\
\text { brackets }\end{array}$} \\
\hline
\end{tabular}

Table 4. Regression models

As it was expected, GDP does not show any significant effect on the cost of equity capital. The analysis focused on a single country seems to be the reason for this absence of significant variations at firm level. In fact, none of the market test variables has any effect on the changes of the cost of equity capital of Spanish listed firms. Surprisingly, firm's size neither has a significant effect on the cost of capital. It is well-documented in the literature that size exhibits a negative relation with expected returns, as a residual risk factor, in any incomplete model of expected returns (Berk, 1995). This anomaly can be explained in terms of the sample size, as an important limitation to capture the full expected effect from our test variables.

Interestingly, and as it was expected as well, we find that firm's beta and financial leverage have a significant and positive effect on the cost of equity capital. Since Sharpe (1964), it is 
assumed that the higher a stock risk is, the higher the expected return by investors. The argument of estimation risk also affects financial leverage, as a higher level of leverage increases the potential investors' estimation risk regarding the parameters of a security's future stocks return.

More importantly, our results show that IFRS adoption is a significant variable to explain variations in the cost of capital of stocks, with negative sign, thus evidencing that the mandatory IFRS adoption has allow Spanish firms to reduce the cost of its equity capital by dropping the required return for its stocks in the period 2005-2009 compared to the preadoption period (1999-2004). This result is consistent with the assertion that a set of highquality accounting standards improves the quality of financial reporting, having a potential benefit effect on the firms' cost of capital if the new accounting standards adoption is implemented along with an effort for enhancing a country's enforcement mechanisms.

\section{Conclusions}

Our paper investigates the economic effects of mandatory IFRS adoption in Spain.

Through the regression of the estimated cost of equity capital of Spanish firms on a set of test variables concerning accounting information, market influence and mandatory IFRS adoption, we have found that risk parameters show a significant and positive effect on stocks' expected returns. If the firm's beta increases then there will be also a rise in the firm's cost of equity capital. Similarly, firms showing a higher financial leverage are associated to a riskier profile and, thus, investors required higher returns to invest in their stocks. Therefore, there is consistent evidence that financial leverage does not only shows a positive influence on shareholders return on equity, but it also has a significant effect on firms' cost of equity capital by increasing the discount rate of future cash flows and, thus, dropping the stocks' value for investors. This discount rate importantly concerns firms' financial policy and it influences capital markets' performance, as a little shift in its value has a huge effect on a firm's stocks market value and on firm's capability to create value.

After controlling by market beta and financial leverage, we find that, unlike Daske et al. (2008) and similarly to Li (2010) results, mandatory IFRS adoption by Spanish firms in 2005 has led to a lower cost of equity capital. Thus, there is a significant and negative joint effect of enhanced quality of financial disclosure and improved enforcement mechanisms on the Spanish stocks' cost of capital of around 150 basis points. This finding is very relevant, as it suggests that a specific analysis by country with additional data for the post-adoption period is required to capture and understand country-level economic consequences of mandatory IFRS adoption. 
This study is subject to several caveats. First, the low size of our sample, due to data availability, may cause that our results do not capture the full effect of explanatory variables, such as the firm's size. Additional country-level analysis with higher samples is required to confirm our findings. Second, as EU countries have been making continuous efforts to strengthen their legal and enforcement systems, our finding seems to be the result of a jointly effect of mandatory IFRS adoption and an enhancing of enforcement mechanisms. Therefore, it is necessary to disentangle this bundled effect in future research at country-level analysis. And, finally, mandatory IFRS adoption is an event with several associated direct and indirect costs and benefits. We have focused on a particular gross capital market benefit from the adoption of international accounting standards, the effect on firms' cost of equity capital, but further research is needed to understand the whole consequences, controlling also by some potential distorting effects stemming from the shocks of economic crisis on financial markets, with a cost/benefit analysis approach, of mandatory IFRS adoption in the EU.

\section{References}

AMIHUD, Y.; MENDELSON, H. (1986). Asset Pricing and the Bid-Ask Spread. Journal of Financial Economics, 17: 223-249. http://dx.doi.org/10.1016/0304-405X(86)90065-6

ARMSTRONG, CH.S.; BARTH, M.E.; JAGOLINZER, A.D.; RIEDL, E.J. (2010). Market Reaction to the Adoption of IFRS in Europe. The Accounting Review, 85(1): 31-61.

http://dx.doi.org/10.2308/accr.2010.85.1.31

ARTIACH, T.C.; CLARKSON, P.M. (2011). Disclosures, conservatism and the cost of equity capital: A review of the foundation literature. Accounting and Finances, 51(1): 2-49. http://dx.doi.org/10.1111/j.1467-629x.2010.00387.x

BARTH, M; LANDSMAN, W.; LANG, M. (2008). International Accounting Standards and accounting quality. Journal of Accounting Research, 46(3): 467-498.

http://dx.doi.org/10.1111/j.1475-679x.2008.00287.x

BERK, J. (1995). A critique of size-related anomalies. Review of Financial Studies, 8(2) (Summer): 275-286. http://dx.doi.org/10.1093/rfs/8.2.275

BERTOMEU, J.; BEYER, A.; DYE, R.A. (2011). Capital Structure Cost of Capital and Voluntary Disclosures. The Accounting Review, 86(3): 857-886. http://dx.doi.org/10.2308/accr.00000037

BOtosAN, C.; PLUMLEe, M.A. (2002). A re-examination of disclosure level and the expected cost of equity capital. Journal of Accounting Research, 40(1): 21-40. 
BOtosAn, C.A.; PLUMLEE, M.A.; WEN, H. (2011). The Relation between Expected Returns, Realized Returns, and Firm Risk Characteristics. Contemporary Accounting Research, 28(4): 1085-1122. http://dx.doi.org/10.1111/j.1911-3846.2011.01096.x

BURGSTAHLER, D.; HAIL, L.; LEUZ, C. (2006). The importance of reporting incentives: Earnings management in European private and public firms. The Accounting Review, 81(5): 983-1016. http://dx.doi.org/10.2308/accr.2006.81.5.983

CLARKSON, P.; GUEDES, J.; THOMPSON, R. (1996). On the Diversification, Observability, and Measurement of Estimation Risk. Journal of Financial and Quantitative Analysis, 31(1): 69-84. http://dx.doi.org/10.2307/2331387

CHRISTENSEN, P.O.; DE LA ROSA, L.E.; FELTHAM, G.A. (2010). Information and the Cost of Capital: An Ex Ante Perspective. The Accounting Review, 85(3): 817-848.

http://dx.doi.org/10.2308/accr.2010.85.3.817

CHRISTENSEN, H.B.; HAIL, L.; LEUZ, C. (2013). Mandatory IFRS Reporting and Changes in Enforcement. Journal of Accounting and Economics, 56(2-3): 147-177.

http://dx.doi.org/10.1016/j.jacceco.2013.10.007

COVRIG, V.; DEFOND, M.; HUNG, M. (2007). Home bias, foreign mutual fund holdings, and the voluntary adoption of International Accounting Standards. Journal of Accounting Research, 45(1): 41-70. http://dx.doi.org/10.1111/j.1475-679x.2007.00226.x

DAMODARAN, A. (2010). Applied Corporate Finance. USA: John Wiley \& Sons.

DASKE, H. (2006). Economic benefits of adopting IFRS or US-GAAP-Have the expected cost of equity capital really decreased?. Journal of Business Finance and Accounting, 33(3-4): 329-373. http://dx.doi.org/10.1111/j.1468-5957.2006.00611.x

DASKE, H.; HAIL, L.; LEUZ, C.; VERDI, R. (2008). Mandatory IFRS Reporting around the World: Early Evidence on the Economic Consequences. Journal of Accounting Research, 46(5): 1085-1142.

DIAMOND, D.; VERRECCHIA, R. (1991). Disclosure, Liquidity and the Cost of Capital. Journal of Finance, 46: 1325-1359. http://dx.doi.org/10.1111/j.1540-6261.1991.tb04620.x

EASLEY, D.; O'HARA, M. (2004). Information and the cost of capital. The Journal of Finance, 59(4): 1553-1583. http://dx.doi.org/10.1111/j.1540-6261.2004.00672.x

EASTON, P. (2004). PE ratios, PEG ratios and estimating the implied expected rate of return on equity capital. The accounting Review, 79(1): 73-95. http://dx.doi.org/10.2308/accr.2004.79.1.73 
ESPINOSA, M.; TROMBETTA, M. (2007). Disclosure Interactions and the Cost of Equity Capital: Evidence from the Spanish Continuous Market. Journal of Business Finance \& Accounting, 34(9): 1371-1392. http://dx.doi.org/10.1111/j.1468-5957.2007.02064.x

FAMA, E.; FRENCH, K. (1997). Industry costs of equity. Journal of Financial Economics, 43(2): 153-194. http://dx.doi.org/10.1016/S0304-405X(96)00896-3

FRANCIS, J.; KHURANA, I.; PEREIRA, R. (2005). Disclosure incentives and effects on cost of capital around the world. The Accounting Review, 80(4): 1125-1162.

http://dx.doi.org/10.2308/accr.2005.80.4.1125

GOSNelL, T.; NeJAdMALAYERI, A. (2010). Macroeconomic News and Risk Factor Innovations. Managerial Finance, 36(7): 566-582. http://dx.doi.org/10.1108/03074351011050316

HAIL, L. (2002). The Impact of Voluntary Corporate Disclosures of the Ex-ante Cost of Capital for Swiss Firms. European Accounting Review, 11(4): 741-773.

http://dx.doi.org/10.1080/0963818022000001109

HAIL, L.; LEUZ, C. (2006). International Differences in Cost of Equity Capital: Do Legal Institutions and Securities Regulation Matter?. Journal of Accounting Research, 44(3): 485-531. http://dx.doi.org/10.1111/j.1475-679x.2006.00209.x

HAIL, L.; LEUZ, C.; WYSOCKI, P. (2010). Global accounting convergence and the potential adoption of IFRS by the U.S. (part I): conceptual underpinnings and economic analysis. Accounting Horizons, 24: 355-394. http://dx.doi.org/10.2308/acch.2010.24.3.355

HUGHES, J.; LIU, J.; LIU, J. (2007). Information asymmetry, diversification, and cost of Capital. The Accounting Review, 82(3): 705-729. http://dx.doi.org/10.2308/accr.2007.82.3.705

KARAMANOU, I.; NISHIOTIS, G.P. (2009). Disclosure and the Cost of Capital: Evidence from the Market's Reactions to Firm Voluntary Adoption of IAS. Journal of Business Finance \& Accounting, 36(7): 793-821. http://dx.doi.org/10.1111/j.1468-5957.2009.02154.x

KOFMAN, P.; MARTENS, M. (1997). Interaction between stock markets: an analysis of the common trading hours at the London and New York stock exchange. Journal of International Money and Finance, 16(3): 387-414. http://dx.doi.org/10.1016/S0261-5606(97)00004-1

LAMBERT, R.; LEUZ, C.; VERRECCHIA, R. (2007). Accounting information, disclosure, and the cost of capital. Journal of Accounting Research, 45(2): 385-420.

http://dx.doi.org/10.1111/j.1475-679x.2007.00238.x

LEE, H-Y; MANDE, V.; SOON, M. (2009). The Effect of the Private Securities Litigation Reform Act of 1995 on the Cost of Equity Capital. Quarterly Journal of Finance and Accounting, 48(2): 85-106. 
LEUZ, C.; VERRECCHIA, R. (2000). The economic consequences of increased disclosure. Journal of Accounting Research, 38 (Supplement): 91-124. http://dx.doi.org/10.2307/2672910

LI, S. (2010). Does Mandatory Adoption of International Financial Reporting Standards in the European Union Reduce the Cost of Equity Capital?. The Accounting Review, 85(2): 607636. http://dx.doi.org/10.2308/accr.2010.85.2.607

MUIÑO, F.; TROMBETTA, M. (2009). Does graph disclosure bias reduce the cost of equity capital?. Accounting and Business Research, 39(2): 83-102.

REVERTE, C. (2009). Do better governed firms enjoy a lower cost of equity capital? Evidence from Spanish firms. Corporate Governance, 9(2): 133-145.

http://dx.doi.org/10.1108/14720700910946587

SHARPE, W. (1964). Capital asset price: a theory of market equilibrium under conditions of risk. Journal of Finance, 19(3): 425-442.

VASSALOU, M. (2003). News related to future GDP growth as a risk factor in equity returns. Journal of Financial Economics, 68(1): 47-73. http://dx.doi.org/10.1016/S0304-405X(02)00248-9 


\section{Apendix A. Firms included in the sample}

Acerinox

ACS

Altadis

Banc de Sabadell

Banco Popular

Banesto

Bankinter

BBVA

$\mathrm{BSCH}$

Cintra

Endesa

Fomento Construcciones y Contratas

Gamesa

Gas natural

Grupo Acciona

Grupo Ferrovial

Iberdrola

Iberia

Inditex

Indra

Mapfre

$\mathrm{NH}$ hoteles

Red Electrica

Repsol

Telefónica

Unión Eléctrica Fenosa

Vallehermoso

Zeltia

Intangible Capital, 2014 (www.intangiblecapital.org)

\section{()}

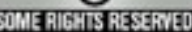

Article's contents are provided on a Attribution-Non Commercial 3.0 Creative commons license. Readers are allowed to copy, distribute and communicate article's contents, provided the author's and Intangible Capital's names are included. It must not be used for commercial purposes. To see the complete license contents, please visit http://creativecommons.org/licenses/by-nc/3.0/. 